\title{
Community Empowerment in Pararem Writing in Belatungan Village, Pupuan, Tabanan, Bali
}

\author{
I Ketut Sukadana ${ }^{1}$, Diah Gayatri Sudibya ${ }^{2}$, Luh Putu Suryani ${ }^{3}$, Ni Made Puspasutari Ujianti ${ }^{4}$, \\ I Wayan Werasmana Sancaya ${ }^{5}$ \\ Lecturer in the Faculty of Law, Universitas Warmadewa, Denpasar, Bali 1 1,2,3,4,5 \\ \{sukadanaketut1966@gmail.com ${ }^{1}$ \}
}

\begin{abstract}
The Community Service Agency empowers the people of Belatungan Village, with partners 1 and 2 associated with the Traditional Village and chief (perbekel), respectively. The problem associated with this community is their inability to design a pararem (customary rules) as a follow-up to the manifestation of existing awig-awig (social institutions). Therefore, this study aims to provide an understanding, equalize perception and realize a pararem in accordance with the norms and needs of the community. Data were obtained through counseling, focus group discussion, and mentoring. The results showed the realization of a village pararem used as a behavior guideline for prajuru desa (village administrators) and krama desa (village residents) in Belatungan Village.
\end{abstract}

Keywords: guidelines; village administrators; villagers

\section{Introduction}

In society, the term customary law at the beginning of its birth is not widely known, what is known is only adat, but in that term the meaning of law is concluded, but in many circles who do not understand customary law in depth they always question that custom is just a habit without any legal element. made to be used as a guide for community members to behave in the hope that their life goals are achieved, for example, their life goals are peace, order, order, welfare, the common good, or justice. If the habit is good, noble, has been realized then, more coercive means are needed. There are special rules in every customary village, villages in customs for krama or people who have village awig-awig to know the rules and obligations of village manners. Krama desa are Hindu people who are small or registered as krama in one of the traditional villages according to the Bali Provincial Regulation No. Own wealth, tradition, inspired by the teachings of Hinduism and the cultural values that live in Bali have a very large role in the field of religion and socio-culture so that they need to be nurtured, preserved and empowered. In Article 1 number 10 of the Bali Provincial Regulation Number 4 of 2019 concerning Traditional Villages in Bali, it states that traditional village manners are "members of the Hindu community who are small and registered as members of the local traditional village."

The desa adat is a traditional village in Bali that has been autonomous since its inception. Each customary village has its own management and assets. Every Traditional Village has the 
authority to make awig-awig, the goal of which is the existence of an order in the life of its community. Initially, awig-awig was not written, but over time there were efforts to make awig-awig written to make it easier to implement. Awig-awig that was formulated, sometimes, unable to anticipate the development of society, and to include it in awig-awig is not easy because it is already in "pasupati", and this can be arranged through pararem. Making a written pararem is also not easy for the community to do, including at this service location, so it is necessary to provide assistance in pararem correspondence (Sudantra, Astiti, \& Laksana, 2017).

Traditional villages that have grown and developed for centuries in Bali have rights of origin, traditional rights, and rights to regulate their own households, have given a very large role in the continuity of community life in the nation and state and in development. The provisions of Article 18B Paragraph (2) of the Constitution of the Republic of Indonesia determine that the state recognizes and respects indigenous peoples and their traditional rights as long as they are still alive and in accordance with the development of society and the principles of the Republic of Indonesia. This is evidence that the state has recognized and guaranteed the existence of a customary community unit constitutionally. This reflects the plurality of legal institutions in Indonesia, namely state law on the one hand and customary law or religious law on the other, and there are even self-regulating arrangements of a local community.

In Bali, there are two villages, namely the traditional village and the official village, the traditional village with its government has awig-awig, prajuru, its own assets to take care of the traditional village household and has genuine autonomy. Traditional villages have a foundation in the form of customary law which is packaged in awig-awig, and is also managed with awig-awig for the benefit of the customary village (Nurjaya, 2011). Based on the provisions of the Bali Provincial Regulation Number 4 of 2019 concerning Traditional Villages in Bali, it has been regulated that one of the authorities of the Traditional Village is to make awig-awig, pararem and other provisions. The following description is supporting latest studies that had been conducted previously such as Fischer \& McKee (2017); Markantoni, Steiner, Meador, \& Farmer (2018); Onyebueke, Walker, Lipietz, Ujah, \& Ibezim-Ohaeri (2020); Ruszczyk et al. (2020); Sudantra et al., (2017). Thus the current study aims to provide an understanding, equalize perception and realize a pararem in accordance with the norms and needs of the community.

\section{Research Method}

The method used in problem solving in this activity is as follows:

a. Conduct a survey of partners

b. Provide an understanding of the concepts in the preparation of pararem

c. Conduct a focus group discussion to explore the substance of the pararem

d. Designing and compiling pararem of partner custom villages

The parties involved as the target of this program are elements of the traditional prajuru which include customary bendesa, pemesan, patengen, kelian, kasinoman, stakeholders, pacalang, as well as from the official elements in partner villages.

\section{Results and Discussion}


This service activity begins with conducting location assessments, then determining the timing of the activity. With the agreement between the community service implementer and the traditional village of Belatungan as partners, counseling, focus group discussion, mentoring, and preparation of traditional village pararem were carried out. The activity was held on March 16, August 11, September 21-22, November 17, 2019. Assistants and extension workers in the pararem arrangement in the Belatungan Traditional Village were I Ketut Sukadana, SH, MH, Diah Gayatri Sudibya, SH, MH, Luh Putu Suryani, SH, MH, Ni Made Puspasutari Ujianti, SH, MH, and I Wayan Werasmana. Sancaya, SH, MHS As a first step in this activity, it is to conduct an awig-awig investigation of customary villages that determine the need for further regulation through pararem. Based on the results of the search for awigawig, it was found that there were 48 pawos (articles) which had to be followed up by making a pararem called the awig penyacah pararem. The classification is as follows:
a. Indik pakraman 8 pawos;
b. Indik prajuru/ ulu desa 5 pawos;
c. Indik kulkul 2 pawos;
d. Indik paruman 2 pawos;
e. Indik druwen desa 1 pawos; 5 pawos;
g. Indik dewa yadnya 11 pawos;
h. Indik pitra yadnya 3 pawos;
i. Indik manusa yadnya 5 pawos;
j. Indik pawiwahan 3 pawos;
k. Indik sentana 2 pawos;
1. Indik warisan 2 pawos;

f. Sukerta pamitegep (pepayonan, wewangunan, wewalungan, bhaya, penyanggran banjar)

In addition, assistance is also provided in the preparation of pangele pararems, namely the creation of pararem which specifically contains matters outside the awig-awig provisions because it regulates things that are new and in accordance with the development (demands) of the community. The Pangele pararem compiled includes plastic waste, drug abuse, rabies, involvement of traditional leaders with investors, gambling, divorce.

\section{Conclusion}

The indigenous village community has increased understanding and capacity in the preparation of the awig and pangele pararem pararem, until finally the awig pararem and pangele pararem of the Belatungan Traditional Village as Partner 1 in this Community Service program can be realized.

\section{References}

[1] Fischer, A., \& McKee, A. (2017). A question of capacities? Community resilience and empowerment between assets, abilities and relationships. Journal of Rural Studies, 54, 187-197. https://doi.org/10.1016/j.jrurstud.2017.06.020

[2] Markantoni, M., Steiner, A., Meador, J. E., \& Farmer, J. (2018). Do community empowerment and enabling state policies work in practice? Insights from a community development intervention in rural Scotland. Geoforum, 97(October), 142-154. 
https://doi.org/10.1016/j.geoforum.2018.10.022

[3] Nurjaya, I. N. (2011). Memahami Kedudukan dan Kapasitas Hukum Adat dalam Politik Pembangunan Hukum Nasional. Perspektif, 16(4), 236. https://doi.org/10.30742/perspektif.v16i4.86

[4] Onyebueke, V., Walker, J., Lipietz, B., Ujah, O., \& Ibezim-Ohaeri, V. (2020). Urbanisation-induced displacements in peri-urban areas: Clashes between customary tenure and statutory practices in Ugbo-Okonkwo Community in Enugu, Nigeria. Land Use Policy, 99(May), 104884. https://doi.org/10.1016/j.landusepol.2020.104884

[5] Ruszczyk, H. A., Upadhyay, B. K., Kwong, Y. M. (Connie), Khanal, O., Bracken, L. J., Pandit, S., \& Bastola, R. (2020). Empowering women through participatory action research in community-based disaster risk reduction efforts. International Journal of $\begin{array}{llll}\text { Disaster Risk } & \text { Reduction, } & \text { 517ugust), }\end{array}$ https://doi.org/10.1016/j.ijdrr.2020.101763

[6] Sudantra, I. K., Astiti, T. I. P., \& Laksana, I. G. N. D. (2017). Sistem peradilan adat dalam kesatuan-kesatuan masyarakat hukum adat desa pakraman di Bali. Jurnal Kajian Bali, 7(1), 85-104. 